\title{
The Relevance of English in Colombian Scientific Research
}

\section{Awareness}

\author{
Jimy Alexander Cortés ${ }^{1} \&$ Iván Darío Arellano $^{1}$ \\ ${ }^{1}$ Department of Physics, Technological University of Pereira, Pereira, Colombia \\ Correspondence: Iván Darío Arellano, Department of Physics, Technological University of Pereira, Carrera 27 \\ \#10-02, Barrio Alamos, PC: 660003, Pereira, Colombia. Tel: 57-6-313-7147. E-mail: arellano@utp.edu.co
}

Received: March 28, 2017 Accepted: April 22, 2017 Online Published: April 24, 2017

doi: 10.5539/elt.v10n5p127 URL: http://doi.org/10.5539/elt.v10n5p127

\begin{abstract}
Even though the majority of Colombian professors are also involved in research, they have limitations in their English language skills that separate them from the rest of the scientific society. Evidently, these limitations have become an obstacle in the awareness of professors' modest, but no less important, research work. In order to carry out this study, we selected three remarkable higher education institutions of Pereira, Risaralda in Colombia. We used collected data from 2012 to 2015. A quantitative analysis of the number of articles in English in comparison to Spanish was done. Even though there has been an increasing number of articles in English, they are still limited. This research suggests an approach to evaluate the hypothesis raised by the authors that states that the low English-language proficiency of the scientists is affecting the visibility of Colombian and, overall, Latin American science. We propose to increase the visibility of Colombian science by publishing research papers in both languages, Spanish and in English. Finally, Latin American English writing skills require attention from their own governments to increase the awareness and contribution of these countries in a globalized world.
\end{abstract}

Keywords: English proficiency, international visibility, scientific research, writing skills, Colombia

\section{Introduction}

English is the de facto language to give a speech in a conference and to write and publish a scientific paper. It is certainly known that most prestigious scientific research journals publish in English, regardless of the native language of the writers. Latin American science has been affected, in some manner, due to the evident low proficiency in this language and Colombia, as part of this continent, is not out of the problem. Actually it is not known what the most important English skill is in order to succeed in international research: writing, reading, listening or speaking. Perhaps, at first glance, speaking and listening could be less imperative, but they also have a remarkable role in being invited as a conference presenter or speaker. In contrast, writing and reading are closely related. Indeed, reading habits give researchers an advantage over those who do not have them. For instance, the more the author reads textbooks and papers in English, the more vocabulary and comprehension he can have in this language. English becomes a huge factor to succeed in publishing internationally.

Submitting a paper to a journal that publishes in English is a challenge all Latin American scientists face, but they do not feel confident to do it due to their low proficiency. The scientific research objective is to publish results internationally; therefore, Latin America has to resolve this English proficiency difficulty as soon as possible to be prepared for the challenges of globalization and its requirements. Furthermore, when authors do not have the proper proficiency in English, they usually must pay an additional fee to have a written review of the submitted paper. This extra cost has a demotivating effect because most researchers are not willing to pay on their own due to the dramatic economic conditions of most Latin American countries where Colombia is also located. Some strategies must emerge to avoid the low English proficiency of some Latin American researchers.

Native speakers do not face the problem of writing and submitting their articles in English in the same way nonnative English speakers do. It is clear that researchers from developed and developing countries, such as Colombia, Peru, and Mexico, among others are interested in publishing their articles in the highest ranking journals, which are mostly in English. This is a big obstacle. Unfortunately, English speaking journals undervalue the great effort that the others must make to overcome this frustrating constraint because they do not offer suitable strategies to change this issue (Vasconcelos et al. 2008, p. 700). For instance, the online Elsevier translation service from Spanish to American English is based on word count per paper and charges 337 USD 
per 550 words which takes 6 days to translate (Elsevier, 2015). Such a situation, Journals in English should widely support authors from non-English speaking countries to allow them introduce their science internationally in a non-profit way as do some associations seeking to attract more public from Latin America.

On the other hand, peer-review evaluation is part of the publishing process that all scientists must face regardless their proficiency in English. For example, Belcher (2007) highlighted the idea that authorial perseverance in the reviewing and submitting of a paper may end up in publication when there are constructive critical comments from evaluators (p. 1). These comments, often critical and even biting, are hard to take, making authors give up after the first rejection of their paper, independent of language proficiency. Therefore a possibility of rejection is not exclusive to a non-native speaker. Perseverance and revision are mandatory to succeed.

All English communicative skills are desirable in the field of research to succeed in publishing. In order to reinforce this idea, Vasconcelos et al. (2008) stated that "Although a high level of proficiency in all four English skills is desirable, competence in writing is an essential component for visibility in academia" (p. 700). Their assumptions were based on a previous study executed in Brazil to evaluate English proficiency of its scientists which indicated low proficiency in writing skills founded on its national and international scientific publications; however, reading and speaking skills were even worse. Later, this paper also stated that scientists who have good writing skills obtain more citations of their articles and are significantly more prolific based on their number of articles, compared to those who are reasonable or poor at it (Vasconcelos et al., 2008, p. 701). Unfortunately, their research is based on Brazil. Though located in Latin America, it is not a Spanish speaking country like most of them are in this part of the continent; however, this gives some insight about our proficiency in English and the relevance of writing in English properly.

Evaluating English proficiency in science is not as simple as it appears because the complexity of scientific papers makes it difficult to estimate each author's proficiency (Shea and Polio, 2014, p. 24). In other words, there are many variables that have to be taken into account: nationality, country size, and research fields, among others. For instance, Latin America has many countries of diverse sizes and populations resulting in a dissimilar number of scientific papers for each country. While researchers in Honduras published just tens papers in 2010, researchers from Brazil, Mexico, and Argentina published thousands, improving their citation impact during the same year. Dentistry, Agricultural \& Biological Sciences, and Veterinary are the subject fields that Latin American science contributes the most; however, this contribution was still under $4.4 \%$ of the world's annual output of scholarly papers in 2010, after combining all research fields (MPhil, 2012, p. 15).

This study address these questions: Is Colombia low proficiency in English affecting the acceptance of peer reviewed papers and its world visibility in that language? What is the most important skill among writing, reading, listening, and speaking? How can Colombian scientists succeed and be competitive internationally? Is it an exclusive issue in Colombia?

The study has determined that writing in English is an essential skill for Latin American science to have global visibility. Research expectations are to raise awareness for the English proficiency issue and, in this way, to invite Colombian scientists to accept the challenge to enhance their English language proficiency.

\section{Method}

A quantitative approach was used to carry out this study. Four years of data (from 2012 to 2015) were provided by three higher education institutions (the Universidad Tecnológica de Pereira UTP, the Universidad Católica de Pereira UCP and Fundación del Area Andina AREANDINA) from Pereira, Colombia to explore the English proficiency of their professors and the amount of scientific publications in English.

\section{Results and Discussion}

The Universidad Tecnológica de Pereira is a leader in scientific publications in English and Spanish among this sample of higher education institutions. This is depicted on Figures 1 and 2; however, the Universidad Católica de Pereira and Fundación del Area Andina have also made a significant effort to overcome this issue. On the other hand, comparing both figures, we have to note that the UTP produced more papers in English than in Spanish during 2015. In the last several years, the UTP has been making a great effort to train and improve the professors' English skills. For the 2015-1016 period, there were 95 professors studying English at the American Colombo Center, and 84 professors were studying in the virtual platform MOE (My Oxford English) (Vicerrectoría Académica Universidad Tecnológica de Pereira, 2016). This is a clear, positive indicator that these institutions are interested in improving their international visibility.

The English proficiency of the professors of the Universidad Tecnológica de Pereira is still too low, according to the Oxford Online Placement Test. Figure 3 shows that $64 \%$ of the professors have an A level of English 
Proficiency, which indicates that they do not understand the language well and find it difficult to participate in a conversation and write. According to Figure 3, only $18 \%$ of the professors do not find difficult to understand the language well. Even though this is a drawback, this institution can improve even more its visibility raising the general English level of its professors. It is also valid for all institutions mentioned.

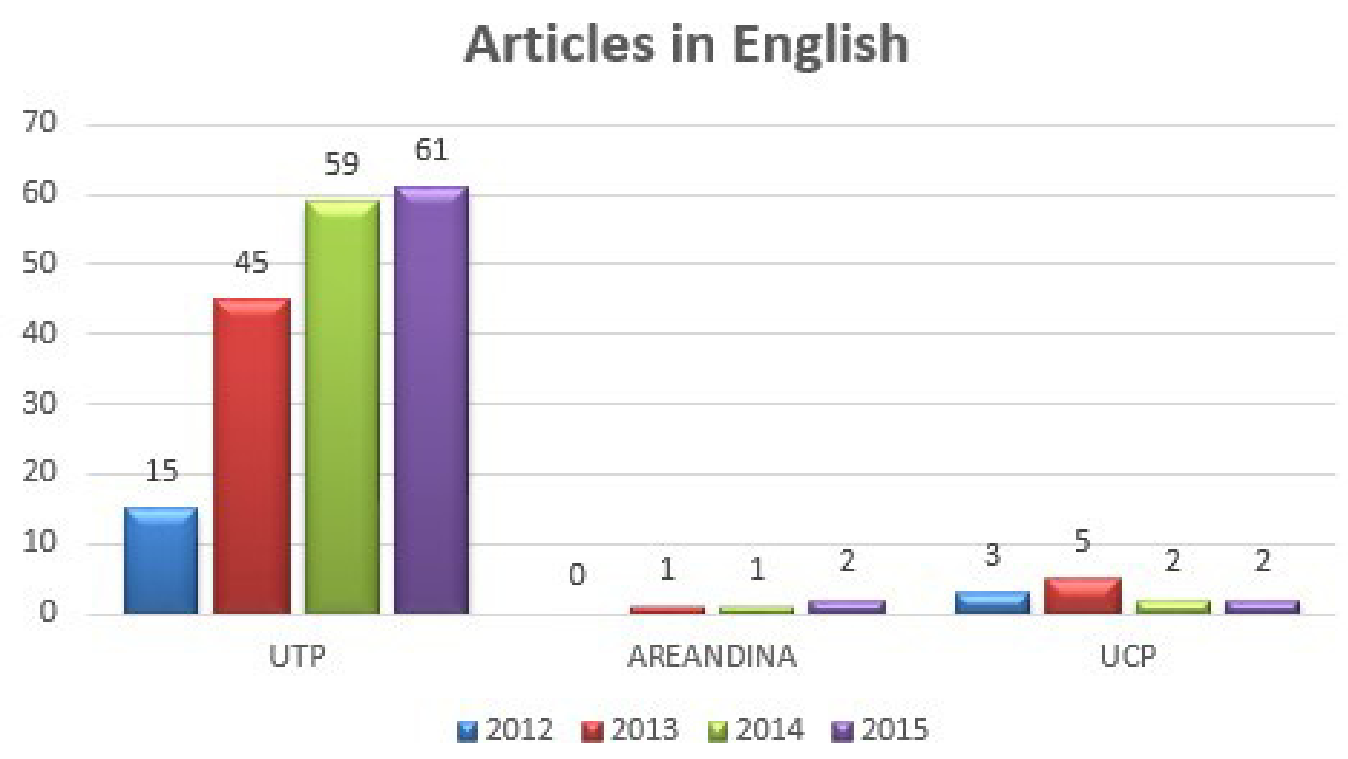

Figure 1. The amount of the articles written in English by the professors of the three studied institutions during last 4 years (CIARP Universidad Tecnológica de Pereira, 2016)

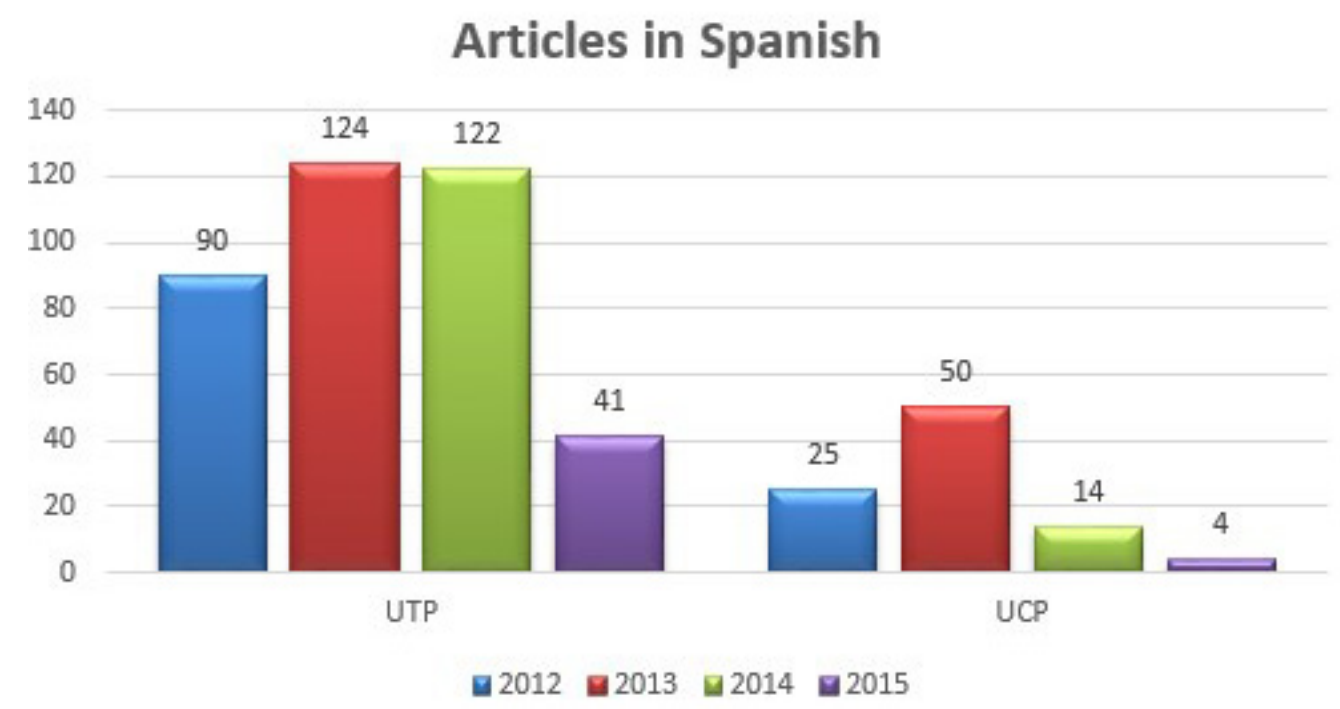

Figure 2. The amount of the articles written in Spanish by the professors of two institutions during last 4 years (CIARP Universidad Tecnológica de Pereira, 2016) (Dirección de Investigaciones e Innovación, Universidad Católica de Pereira, 2016)

'Colombia Bilingue' is an ambitious project of the Colombian government and its Ministry of Education to increase the English proficiency of primary and high school students ('Lenguas Extranjeras', 2017). As part of its future consequences from 2018 and on, English courses will be mandatory in higher education institutions to obtain the 'Registro Calificado' (Qualified Registration) which checks and ensures quality conditions in the academic programs of undergraduate programs in Colombia (' $¿ Q u e ́$ es el Registro Calificado? - Sistemas 
información', 2017). Another possible outcome of these policies is an expected increment of international papers published in English. All these may be a slight effort; however, it could dramatically affect the international visibility of Colombian science in a positive way if accomplished satisfactorily.

Moreover, Pereira's mayor and the Chamber of Commerce have also established an additional strategy to increase the competitivity of their city. 'Pereira Bilingue' is carrying this out through the NGO 'Voluntarios Colombia' and World Teach, the latter is a non-profit organization created by a group of Harvard students to respond to the need for educational assistance to children and poor youth in developing countries ("Alcaldía de Pereira y Camara de Comercio le apuestan a la educación bilingüe - Centro Virtual de Noticias de Educación', 2017).

\section{UTP PROFESSORS}

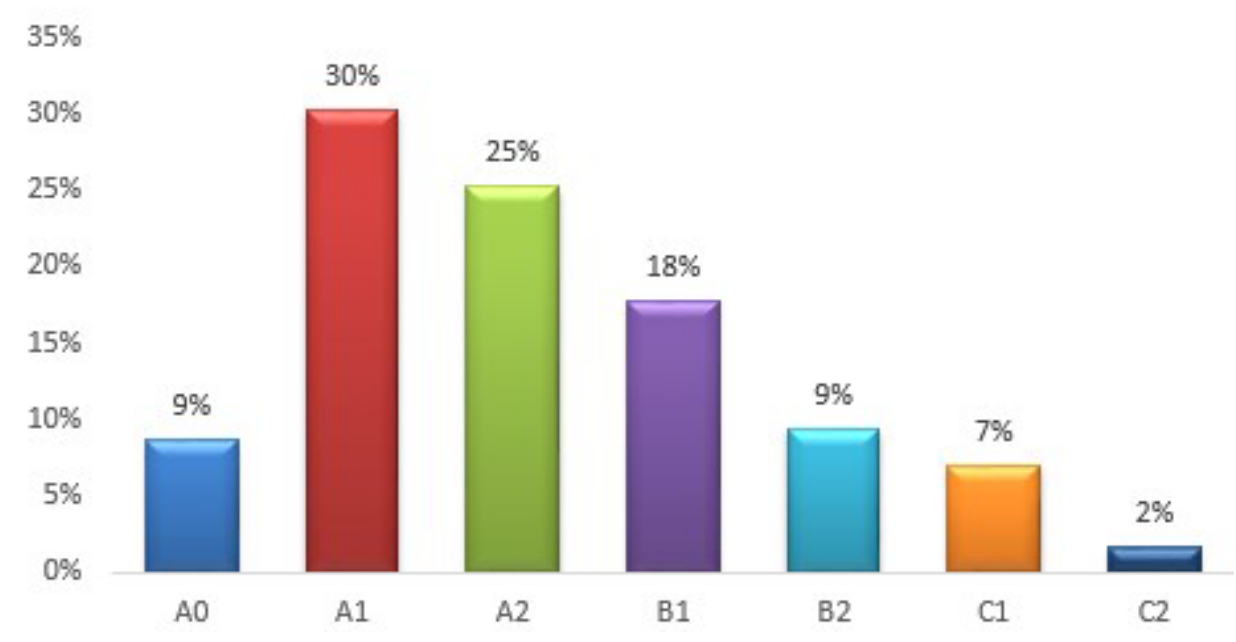

Figure 3. Level of English of UTP professors according to Oxford Online Placement Test (Vicerrectoría Académica Universidad Tecnológica de Pereira, 2016)

\section{Conclusion}

There are some ideas to mitigate the low visibility of Colombian and, overall, Latin American science. The first proposal is to increase the visibility of Colombian science by publishing research papers in both the native language and in English. Though this can be academically beneficial, it is not mandatory in the majority of developing countries (Meneghini and Packer, 2007, p114). This should be more than just a requirement of all Latin American journals. There needs to be a strategy to accomplish it. Another complementary strategy could be to improve education in English as a Foreign Language from primary school, such as it is in many European countries (Truchot, 2002, p. 8). It also could be a crucial step to increase the awareness of Latin American countries and, improve the visibility of Latin American science through the students who become scientists. Another idea is that even though writing is one of the most important skills needed, reading must be taken into account to have an updated view of science while studying textbooks and papers. It is known that some of these well-known academic sources are first written in English, so the more researchers read them in English, the more fluently they can write in that language. Even though all English skills are desirable, the most important skills are writing and reading because they favor the production of scientific papers, and, by doing so, the rise of scientific citation impact which increases scientific awareness of countries.

Ranking U-Sapiens, a classification of Colombian universities developed by Sapiens Research Group, ranks higher education institutions based on these indicators: the number of journals indexed in Publindex, the number of research-based masters or doctorates that have to do with research and seed research to develop such projects ('Ranking U-Sapiens 2015-1', 2016). It must be noted that the Universidad Tecnológica de Pereira, which is one of the sample institution we used, is ranked $12^{\text {th }}$ in the country. In addition, Scimago Institution rank has established that the Universidad Tecnologica de Pereira is ranked $10^{\text {th }}$ in Colombia next to all institutions in 2016. ('Scimago Institutions Rankings', 2016). Therefore, there is undeniable evidence that the more scientific publications are written in English, the higher the international awareness is. 
One final important conclusion can be cited from Salager-Meyer (2008) who concludes in his paper that "to 'universalize science' indeed means not only to cooperate actively in its creation but also to extend the fruit of its applications to the whole of humankind so that not only Europeans, North Americans, Japanese or the well-off classes of developing countries, i.e., a privileged few, but humankind as a whole, will be able to enjoy the benefits that science and technology can provide and the opportunities these benefits bring" (p. 129). In consequence, this limitation, in Latin American English writing skills, requires attention from all Latin American governments to increase the awareness and contribution of these countries in a globalized world. Colombia is not an exception.

\section{Acknowledgments}

The authors would like to thank Fundación del Area Andina, Universidad Católica de Pereira, and Universidad Tecnológica de Pereira for their raw data of national and international papers published that supported this research. Last but not least, we also acknowledge the assistance and support we received from some teachers of the English Language Institute at Missouri State University, who provided unvaluable comments during the writing of the first version of this paper.

\section{References}

Alcaldía de Pereira y Cámara de Comercio le apuestan a la educación bilingüe - Centro Virtual de Noticias de Educación. (2017). Mineducacion.gov.co. Retrieved 18 February 2017, from http://www.mineducacion.gov.co/cvn/1665/w3-article-308577.html

Belcher, D. Diane. (2007, January). Seeking acceptance in an English-only research world. Journal of Second Language Writing, 16, 1-22. https://doi.org/10.1016/j.jslw.2006.12.001

CIARP Universidad Tecnológica de Pereira. (2016). Informe Artículos publicados en Inglés y Español del 2012-2016. Unpublished raw data.

Dirección de Investigaciones e Innovación, Universidad Católica de Pereira, (2016). Reporte de producción académica total 2012-2015. Unpublished raw data.

Elsevier. (2015). Transparent pricing for Translation services. In Elsevier Webshop. Retrieved July 23, 2015, from http://webshop.elsevier.com/languageservices/translationservices/pages/pricing.html

Lenguas Extranjeras. (2017). Colombiaaprende.edu.co. Retrieved 18 February 2017, from http://www.colombiaaprende.edu.co/html/micrositios/1752/w3-article-315515.html

Meneghini, R., \& Packer, A. L. (2007, February). Is there science beyond English? Initiatives to increase the quality and visibility of non-English publications might help to break down language barriers in scientific communication. EMBO Reports, 8(8), 112-116. https://doi.org/10.1038/sj.embor.7400906

MPhil, S. H. (2012, November). The Rise of Latin American science. Research Trends, 15-18. Retrieved July 19, 2015, from http://www.researchtrends.com/wp-ontent/uploads/2012/11/Research_Trends_Issue_31.pdf

¿Qué es el Registro Calificado? - Sistemas información. (2017). Mineducacion.gov.co. Retrieved 27 January 2017, from http://www.mineducacion.gov.co/sistemasdeinformacion/1735/article-241150.html

Ranking U-Sapiens 2015-1. (2016). Sapiensresearch.org. Retrieved 13 July 2016, from http://www.sapiensresearch.org/usapiens/2015-1/

Salager-Meyer, F. (2008, April). Scientific publishing in developing countries: Challenges for the future. Journal of English for Academic purposes, 7, 121-132. https://doi.org/10.1016/j.jeap.2008.03.009

Scimago Institutions Rankings. (2016). Scimagoir.com. Retrieved 28 July 2016, from http://www.scimagoir.com/rankings.php?country=COL

Shea, M. C., \& Polio, C. (2014, December). An investigation into current measures of linguistic accuracy in second language writing research. Journal of Second Language Writing, 26, 10-27. https://doi.org/10.1016/j.jslw.2014.09.003

Truchot, C. (2002). Key aspects of the use of English in Europe. Unpublished Report, DGIV, Council of Europe, Strasbourg

Vasconcelos, S. M., Sorenson, M. M., Leta, J., Santana, M. C., \& Batista, P. D. (2008, August 1). Researchers' writing competence: a bottleneck in the publication of Latin-American science? EMBO Reports, 9, 700-702. https://doi.org/10.1038/embor.2008.143

Vicerrectoría Académica Universidad Tecnológica de Pereira, (2016). Formación en segunda Lengua 
Universidad Tecnológica de Pereira. Pereira: Unpublished raw data.

\section{Copyrights}

Copyright for this article is retained by the author(s), with first publication rights granted to the journal.

This is an open-access article distributed under the terms and conditions of the Creative Commons Attribution license (http://creativecommons.org/licenses/by/4.0/). 